\title{
Records of Inorganic lons and Dust Particles in Snow at Yushugou Glacier No. 6 in the Desert Belt of Northwestern China
}

\author{
Feng Liu ${ }^{1,2}$, Zhongqin $\mathrm{Li}^{3,4,5 *}$, Jianan $\mathrm{Hao}^{6}$, Xi Zhou ${ }^{6}$, Fanglong Wang ${ }^{4}$, Hui Zhang ${ }^{2,4}$, \\ Panpan Wang ${ }^{3}$, Xin Zhang ${ }^{4}$, Mengyuan Song ${ }^{4}$ and Taotao Chen ${ }^{3}$
}

${ }^{1}$ Institute of International Rivers and Eco-security, Yunnan University, Kunming, Yunnan, China, ${ }^{2}$ Yunnan Key Laboratory of International Rivers and Transboundary Eco-security, Kunming, China, ${ }^{3}$ College of Geography and Environmental Sciences, Northwest Normal University, Lanzhou, China, ${ }^{4}$ State Key Laboratory of Cryospheric Science, Northwest Institute of EcoEnvironment and Resources, Chinese Academy of Sciences, Lanzhou, China, ${ }^{5}$ College of Sciences, Shihezi University, Xinjiang, China, ${ }^{6}$ College of Earth and Environmental Sciences, Lanzhou University, Lanzhou, China

\section{OPEN ACCESS}

Edited by:

Khanghyun Lee,

Korea Polar Research Institute,

South Korea

Reviewed by:

Yong Zhang,

Hunan University of Science and

Technology, China

Jizu Chen,

Chinese Academy of Sciences (CAS),

China

Parmanand Sharma,

National Centre for Polar and Ocean

Research (NCPOR), India

*Correspondence:

Zhongqin $\mathrm{Li}$

lizq@/zb.ac.cn

Specialty section: This article was submitted to

Cryospheric Sciences,

a section of the journal

Frontiers in Earth Science

Received: 16 January 2020 Accepted: 30 September 2020 Published: 12 November 2020

Citation:

Liu F, Li Z, Hao J, Zhou X, Wang F, Zhang $H$, Wang $P$, Zhang $X$, Song $M$

and Chen $T$ (2020) Records of Inorganic lons and Dust Particles in Snow at Yushugou Glacier No. 6 in the Desert Belt of Northwestern China.

Front. Earth Sci. 8:527493.

doi: 10.3389/feart.2020.527493
Chemical ions and dust particles deposited in snow can be used as indicators of climatic and environmental processes. Understanding their sources, energy transfer, and evolutionary mechanisms is extremely important in tracking regional climate and environmental changes. We collected snow samples from three pits at different altitudes and from the surface of Yushugou Glacier No. 6, Tian Shan Mountains, China, in the summers of 2017 and 2018. Sea-salt tracing, correlation analysis, and factor analysis were used to determine the characteristics and sources of the major ions and mineral dust particles in the snow. We found obvious seasonal variations, with high concentrations of dust particles and major ions deposited during the dust period, and relatively low concentrations deposited during the non-dust period. The concentrations peaked within two distinct dust layers in the snow pits. There was a significant correlation between the peak values and the dust layer. The ionic concentrations were ranked from highest to lowest as $\mathrm{Ca}^{2+}>\mathrm{SO}_{4}{ }^{2-}>\mathrm{Cl}^{-}>\mathrm{Na}^{+}>\mathrm{NO}_{3}{ }^{-}>$ $\mathrm{NH}_{4}{ }^{+}>\mathrm{Mg}^{2+}>\mathrm{K}^{+}$. Therefore, $\mathrm{SO}_{4}{ }^{2-}$ was the dominate anion and $\mathrm{Ca}^{2+}$ was the dominate cation. The major ions in the snow at Yushugou Glacier No. 6 are mainly derived from terrestrial mineral dust but also include limited inputs from human activities and sea salt.

Keywords: Yushugou Glacier No. 6, accumulated snow, chemical characteristics, seasonal variation, ionic sources

\section{INTRODUCTION}

The cryosphere is a part of the Earth's surface where temperatures are continuously below the freezing point of water. It can be divided into continental, marine, and aerial components, consisting of glaciers, ice sheets, frozen ground, snow, sea ice, etc. (Qin et al., 2017). It is well known that the cryosphere is very sensitive to climate change and is therefore considered a barometer of it (Qin et al., 2006; Koven et al., 2013; Kraaijenbrink et al., 2017). Snow and ice in alpine glaciers contain a record of the chemistry of the atmosphere (Fuhrer et al., 1996; Olivier et al., 2006). Chemical studies on ice and snow in alpine glaciers are important because snow and glaciers can provide crucial information about climatic and environmental change as they are sites where atmospheric chemical components are deposited; for example, chemical ions, aerosol dust particles, trace metals, $\delta^{18} \mathrm{O}$, greenhouse gases, and black carbon (Ming et al., 2009; Massling et al., 2015; Sugimoto et al., 2015; Du et al., 2016; 
Van der A. et al., 2017). Identification of the origins and seasonal changes of the chemical components in snow may provide information about changes in the atmosphere, lithosphere, hydrosphere, and cryosphere (Prospero et al., 2002). Generally, chemical ions and dust particles deposited in snow reflect the influences of both atmospheric circulation patterns and the regional environment (Eichler et al., 2001; Li et al., 2007; Ming et al., 2009). Taking the Tibetan Plateau as an example, under the influence of a southwest monsoon climate and northwest drought climate, distinct regional climate patterns are formed. Similarly, differences in the geographical environment are also reflected in the snow and ice on the Tibetan Plateau (Liu et al., 2010; Wu et al., 2011). For example, the amount of dust particles in snow tends to decrease from north to south.

There has been comprehensive research on dust particles, their chemical compositions, and related topics in the snow and ice of the Tian Shan Mountains. Wu and Yao (2005) used HYSPLIT back-trajectory modeling to suggest that westerly winds, the arctic air mass, and local prevailing winds are the main ways that dust is brought to the eastern Tian Shan Mountains. Wang et al. (2013) studied the distribution and environmental significance of nitrate and ammonium in snow on glaciers in the Tian Shan Mountains. They proposed that the spatial distribution of nitrogen-containing ions is influenced by longdistance pollution and atmospheric dust, local anthropogenic outputs such as industry and agriculture, as well as the sampling conditions. You et al. (2019) studied the relationship between ion leaching and meteorological elements on Urumqi Glacier No. 1, finding that the ionic concentration in snow cover decreased with increases in temperature, while precipitation had a relatively weak influence. In addition, some scholars have achieved useful results by studying other glaciers in the Tian Shan Mountains, such as Bogda Glacier (Zhang and Edwards, 2011), Haxilegen Glacier No. 51 (Dong et al., 2011), and Miaoergou Glacier in Hami Prefecture (Chen et al., 2015). These achievements have laid a foundation for the study of snow and ice chemistry in the western alpine mountains of China.

Dust particles are also an important indicator of atmospheric changes associated with changes in temperature, precipitation, and atmospheric circulation (Dong et al., 2011). Central Asia is a major dust source region of the Northern Hemisphere (Dong et al., 2013), from which large amounts of dust are transported to North China, Japan, Korea, the North Pacific, North America, and even the Arctic Greenland ice sheet by atmospheric circulation such as westerly winds (Dong et al., 2014; Wang et al., 2014). The dust concentrations observed in ice or snow result from a combination of interrelated mechanisms, ranging from dust mobilization in source areas by uplift and long-range transport, to deposition onto ice sheets (Ruth et al., 2003; Niu et al., 2017). Long-range transport of contaminants via atmospheric circulation is an important pathway for the accumulation of environmental pollutants in remote regions (Jackson, 1997; Fitzgerald et al., 1998; Niu et al., 2017).

The study area was located in the center of an arid region surrounded by many deserts, such as the Gulbantonggu Desert, Kumtag Desert, and other desertified regions, where dust storms are the main atmospheric phenomenon. Regional differences in the distribution of the geographical environment and atmospheric circulation system determine regional differences in the chemical composition of snow and ice. Dust particles in snow and ice can change the albedo of glaciers, thus affecting their energy balance, accelerating melting and, ultimately, affecting regional water cycles. Therefore, research into the characteristics of dust deposition and its seasonal changes in glacierized regions has become an urgent scientific mission. So far, there has been little in-depth study of the dust layer formation process and variations in particles in the snow of Yushugou Glacier No. 6. Furthermore, the connections between dust storm activity and the deposition mechanisms of particles and ions in snow remain unclear. Therefore, it is necessary to conduct research on particles and ions in snow and ice in Yushugou Glacier No. 6 and compare the results with existing research on other glacierized regions in Tian Shan. This will have two main benefits. 1) It has important theoretical significance for improving models of atmospheric dust circulation and deposition in arid regions of northwest China. 2) It will have extremely important practical significance for exploring regional climate change, water resource dynamics, and ecology construction. This study analyses the chemical characteristics of and seasonal variations in dust particles and major ions in snow collected from Yushugou Glacier No. 6 in the eastern Tian Shan Mountains in the summers of 2017 and 2018. Furthermore, backward trajectory analysis is employed to examine the air mass transport processes relevant to this glacier.

\section{MATERIALS AND METHODS}

\section{Study Area and Sampling Strategy}

The eastern Tian Shan Mountains lie in the center of arid and semi-arid areas in northwest China. They are surrounded by many deserts, which are source areas for dust activity in central Asia. Yushugou Glacier No. $6\left(43^{\circ} 03^{\prime} \mathrm{N}, 94^{\circ} 57^{\prime} \mathrm{E}\right)$ is located on the southern slope of Harrick Mountain at the end of eastern Tian Shan (Figure 1). It is a typical alpine glacier with an area of $4.06 \mathrm{~km}^{2}$ (Wang et al., 2017). According to meteorological data from Yushugou Station, the annual maximum temperature in Yushugou Basin is $34.2^{\circ} \mathrm{C}$ and the annual minimum temperature is $-25.8^{\circ} \mathrm{C}$, with an average annual temperature of $5.9^{\circ} \mathrm{C}$ (Ming et al., 2009). Affected by westerly winds, the precipitation in this area is mainly concentrated in summer $(79.6 \%$ of annual precipitation). From October to March, precipitation is rare (14.5\% of annual precipitation) and mainly falls as snow (Luo et al., 1999).

Three snow pits were excavated at different altitudes in Yushugou Glacier No. 6. Samples were collected from Snow pit 1 (Sp-1) in August 2017, Snow pit 2 (Sp-2) in August 2018, and Snow pit 3 (Sp-3) in early June 2018. The sampling depths were $\mathrm{Sp}-1=1.2 \mathrm{~m}, \mathrm{Sp}-2=1.2 \mathrm{~m}$, and $\mathrm{Sp}-3=1.0 \mathrm{~m}$. A total of 102 snow samples were obtained from the three snow pits. Additionally, 42 surface snow samples were taken at altitudes of 3,800-4,500 $\mathrm{m}$ in August 2018. The sampling process was carried out in strict accordance with snow and ice sampling procedures (Wake et al., 1994; Niu et al., 2013). The selection of snow pit sampling points is very important. We selected relatively flat, 


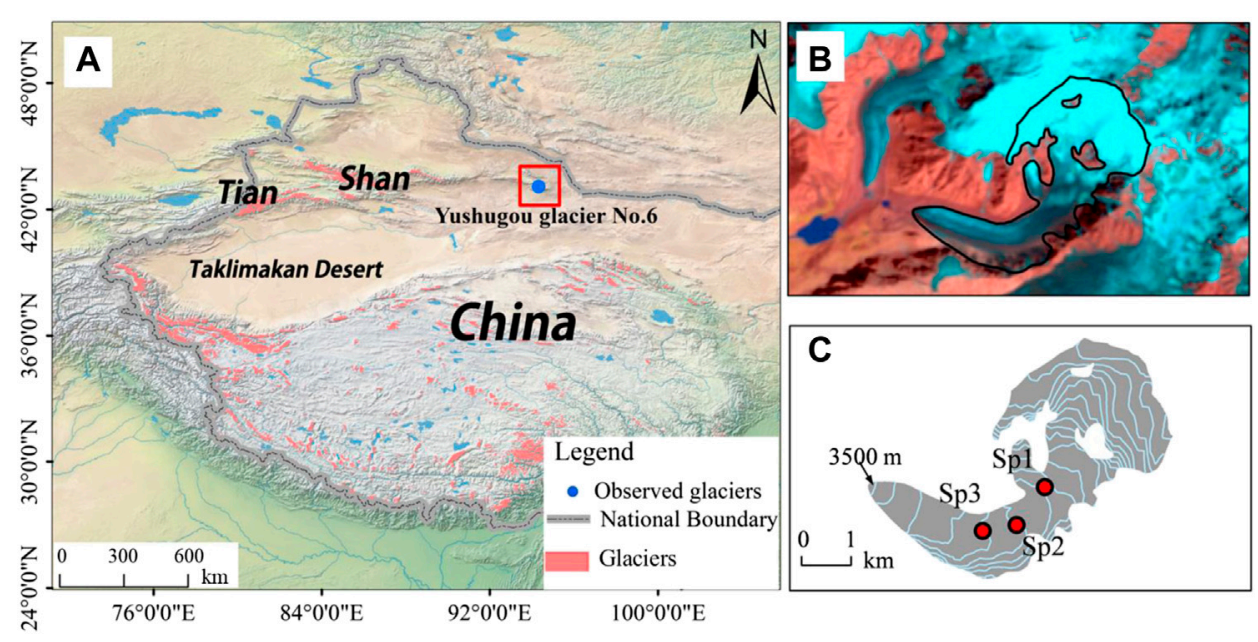

FIGURE 1 | Regional setting of Yushugou Glacier No. 6: (A) location in China; (B) satellite image with the glacier outlined; (C) topographic map of the glacier and the sampling sites in 2017 and in 2018, contour interval $=100 \mathrm{~m}$.

shaded surfaces receiving low sunshine, as such conditions benefit the preservation of snow records (Wang et al., 2017). Sample collection was carried out in strict accordance with purification and pollution prevention requirements. Before sampling, all sample bottles, sampling tools, processing equipment, work clothes, and other equipment were cleaned with deionized water. Polyethylene gloves and face masks were used to avoid contamination of samples. Operators wore cleanroom clothes and the sampling tubes were inserted and removed manually. The sampling tubes had been previously acid-washed $\left(0.05 \% \mathrm{HNO}_{3}\right)$ and individually checked by inductively coupled plasma mass spectrometry (ICP-MS) to ensure there was no significant contamination. Immediately after sample collection, the tubes were sealed inside polypropylene bags and stored at $-18^{\circ} \mathrm{C}$ until analysis. In addition, records were made of the weather conditions, snow pit depth, sampling interval, snow layer characteristics (e.g., dust layer, snow grain size, and hardness), etc. (Qin et al., 1999; Zhang et al., 2007; Wang et al., 2008).

\section{Sample Transportation and Instrument Analysis}

Alpine glaciers are mostly distributed in inaccessible mountainous areas. Care must be taken to ensure the integrity of snow samples, particularly in relation to maintaining a constant temperature. Samples were transported in an incubator containing ice cubes. The temperature in the incubator was checked every $4 \mathrm{~h}$ and ice cubes were added as necessary to avoid temperature increases. Transport of samples from the field to the laboratory freezer usually took 1-3 days. All samples were analyzed at the State Key Laboratory of Cryospheric Science. Particle analysis was performed using an optical particle detector (Accusizer $780 \mathrm{~A}$ ) equipped with a 120-orifice by the single-particle optical sensing (SPOS) method (Zhu et al., 2006; Li et al., 2010). Measurements were performed under class 100 conditions on sample aliquots diluted with a pre-filtered $\mathrm{NaCl}$ solution to obtain a $2 \%$ vol. electrolyte concentration. The range of measurable diameters was $0.57-400 \mu \mathrm{m}$. Routine analysis of filtered deionized water blanks showed background counts to be, on average, 10 times lower than those in samples. Background counts were subtracted from the sample data. All samples were analyzed in triplicate in random order. Results were then averaged for individual samples, yielding an estimated error in particle concentration of $\leq 10 \%$ (Steffensen, 1997; Li et al., 2010). The concentrations of cations $\left(\mathrm{Ca}^{2+}, \mathrm{Mg}^{2+}, \mathrm{Na}^{+}, \mathrm{K}^{+}\right.$, and $\left.\mathrm{NH}_{4}^{+}\right)$ were detected by an ion chromatograph (Dionex-600) and the concentrations of anions $\left(\mathrm{SO}_{4}{ }^{2-}, \mathrm{NO}_{3}{ }^{-}\right.$, and $\left.\mathrm{Cl}^{-}\right)$were detected by a similar machine (Dionex-300) with a measurement accuracy of $10^{-9} \mathrm{~g} \mathrm{ml}^{-1}$ and a measurement error of $<5 \%$.

\section{Research Methods}

Factor analysis is a multivariate statistical method. A mathematical model of factor analysis is established on the basis of mass conservation. The basic idea is as follows: According to the analysis of the loading of each factor on each variable, the main factor is determined and the source of the load ion is judged according to its chemical properties (Blifford and Meeker, 1967). The study area was located downwind of the Central Asian sand and dust area, which is strongly affected by westerly winds. Therefore, this study used sea-salt tracer methods to explore the sources of ions. The core of this method is the selection of sea-salt tracer ions (Church et al., 1982; Keene et al., 1986). The determination principle is as follows:

(1) If the equivalent ratios of $\mathrm{Mg}^{2+} / \mathrm{Cl}^{-}$and $\mathrm{Na}^{+} / \mathrm{Cl}^{-}$ concentrations are greater than those of standard seawater $\left(\mathrm{Na}^{+} / \mathrm{Cl}^{-}=0.859, \mathrm{Mg}^{2+} / \mathrm{Cl}^{-}=0.195\right)$, then $\mathrm{Cl}^{-}$can be used as the sea-salt tracing ion.

(2) If the equivalent ratios of $\mathrm{Na}^{+} / \mathrm{Mg}^{2+}$ and $\mathrm{Cl}^{-} / \mathrm{Mg}^{2+}$ concentrations are greater than those of standard seawater $\left(\mathrm{Na}^{+} / \mathrm{Mg}^{2+}=4.403, \mathrm{Cl}^{-} / \mathrm{Mg}^{2+}=5.126\right)$, then $\mathrm{Mg}^{2+}$ can be used as the sea-salt tracing ion. 
TABLE 1 | Properties of dust, pH, EC, and main ionic concentrations in snow pits and surface snow at Yushugou Glacier No. 6.

\begin{tabular}{|c|c|c|c|c|c|c|c|c|c|c|c|c|}
\hline \multirow[t]{2}{*}{ Sampling site } & \multirow{2}{*}{$\begin{array}{c}\text { Altitude } \\
\text { (m) }\end{array}$} & \multirow[t]{2}{*}{$\mathrm{pH}$} & \multirow{2}{*}{$\begin{array}{c}E C \\
\left(\mu \mathrm{cm}_{-1}\right)\end{array}$} & \multirow{2}{*}{$\begin{array}{c}\text { Dust } \\
\left(10_{3} \mathrm{ml}_{-1}\right)\end{array}$} & \multicolumn{8}{|c|}{ Ion concentrations $\left(\mu \mathrm{g} \cdot \mathrm{L}^{-1}\right)$} \\
\hline & & & & & $\mathrm{Ca}^{2+}$ & $\mathrm{SO}_{4}{ }^{2-}$ & $\mathrm{Cl}^{-}$ & $\mathrm{Na}^{+}$ & $\mathrm{NO}_{3}^{-}$ & $\mathbf{K}^{+}$ & $\mathbf{M g}^{2+}$ & $\mathrm{NH}_{4}^{+}$ \\
\hline Snow pit 1 & 4,200 & 5.6 & 3.3 & 302 & 74.7 & 62.1 & 50.4 & 52.1 & 36.5 & 26.5 & 24.7 & 37.1 \\
\hline Snow pit 2 & 4,000 & 5.7 & 3.5 & 425 & 135.7 & 126.1 & 80.2 & 55.5 & 49.0 & 27.0 & 26.5 & 48.8 \\
\hline Snow pit 3 & 3,900 & 5.7 & 3.3 & 894 & 172.7 & 158.2 & 107.6 & 85.4 & 64.8 & 29.6 & 28.1 & 66.6 \\
\hline Mean value & 4,033 & 5.6 & 3.4 & 540 & 132.5 & 124.6 & 85.2 & 69.8 & 56.4 & 28.7 & 27.4 & 51.4 \\
\hline Surface snow & $3,800-4,500$ & 5.5 & 2.9 & 342 & 142.0 & 72.7 & 51.2 & 45.1 & 42.6 & 23.1 & 27.3 & 58.5 \\
\hline Non-marine source (\%) & & & & & 99 & 96 & 66 & 59 & 95 & 91 & 90 & 89 \\
\hline Marine source (\%) & & & & & 1 & 4 & 34 & 41 & 5 & 9 & 10 & 11 \\
\hline
\end{tabular}

(3) If the equivalent ratios of $\mathrm{Cl}^{-} / \mathrm{Na}^{+}$and $\mathrm{Mg}^{2+} / \mathrm{Na}^{+}$ concentrations are greater than those of standard seawater $\left(\mathrm{Cl}^{-} / \mathrm{Na}^{+}=1.165, \mathrm{Mg}^{2+} / \mathrm{Na}^{+}=0.227\right)$, then $\mathrm{Na}^{+}$can be used as the sea-salt tracing ion.

After selecting a sea-salt tracer ion, we use the formula:

$$
N_{\mathrm{NNA}}=C_{\mathrm{A}}-R \cdot C_{\mathrm{M}} \text {, }
$$

where $N_{\mathrm{NNA}}$ is the non-marine source part of $\mathrm{A}, C_{\mathrm{A}}$ represents the measured concentration of $\mathrm{A}, \mathrm{M}$ is the sea salt tracer ion, $C_{\mathrm{M}}$ represents the measured concentration of $\mathrm{M}$, and $R$ is the ratio of A to $M$ in standard sea salt.

In addition, the HYSPLIT back-trajectory model was used to simulate the trajectories of air masses reaching Yushugou Glacier No. 6. This model has been widely used in source analyses of aerosols, dust particles, and ions (Mukai and Suzuki, 1996; Lammel et al., 2003; Ming et al., 2009). The analysis is based on the HYSPLIT 4.8 model, which includes the vertical motion pattern of the atmosphere. The backward transport trajectory of the atmospheric air mass at the glacier sampling sites was analyzed and calculated within 3 days.

\section{RESULTS AND DISCUSSION}

\section{Characteristics of lons and Dust Particles}

Table 1 shows the $\mathrm{pH}$, EC (electrical conductivity), dust, and concentration values for the major ions found in Yushugou Glacier snow pits and surface snow, as well as their composition characteristics. The ranking of ionic concentrations was, from high to low, $\mathrm{Ca}^{2+}>\mathrm{SO}_{4}{ }^{2-}>\mathrm{Cl}^{-}>$ $\mathrm{Na}^{+}>\mathrm{NO}_{3}{ }^{-}>\mathrm{NH}_{4}{ }^{+}>\mathrm{Mg}^{2+}>\mathrm{K}^{+}$, in which $\mathrm{SO}_{4}{ }^{2-}$ and $\mathrm{Ca}^{2+}$ were the main anions and cations, respectively. Dibb et al. (2007) found that the main cations and anions in snow on the Greenland Ice Sheet were $\mathrm{NH}_{4}{ }^{+}$and $\mathrm{NO}_{3}{ }^{-}$. This is quite different from our result, reflecting regional differences in the chemical ions deposited in snow. Alkaline $\mathrm{Ca}^{2+}$ in glacial snow is an indicator of Asian dust, and its concentration usually has a good correlation with the concentration of mineral dust in snow. In particular, the concentrations of $\mathrm{SO}_{4}{ }^{2-}$ and $\mathrm{Ca}^{2+}$ in glacial snow in the Asian dust source area are higher than those in marine glaciers and polar regions. The average concentrations of ions in the snow pits were higher than those in the surface snow. Similarly, the conductivity of the snow pits was higher than that of the surface snow. This is most probably because the surface snow contains the recent snowfall in the glacier area, while the snow in pits represents the accumulation of snow and atmospheric chemicals over a long period of time (Niu et al., 2013).

The concentrations of ions and dust particles in different snow pits also differed. According to Table 1 and Figure 2, the elevations of the three snow pits were different. Sp-1 was highest $(4,200 \mathrm{~m})$ and its concentrations of ions and dust particles were the lowest. Sp-2 was at the middle elevation $(4,000 \mathrm{~m})$ and its concentrations were moderate. Sp-3 had the lowest elevation $(3,900 \mathrm{~m})$ and the highest concentrations of ions and dust particles. This phenomenon shows an obvious altituderelated effect. Generally, the ions and dust particles in snow pits are deposited by a combination of precipitation and dry deposition. According to the analysis, the concentrations of dust particles and ions from the Earth's surface and ions carried by vapor from the Atlantic and central Asian lakes will gradually decrease with increasing elevation of the glaciers. On the one hand, this may be related to the altitude that vapor transport can reach. Liu used TRMM precipitation data to calculate that the maximum precipitation on the south slope of Harrick Mountain occurred at elevations of 3,500-3,900 m (Liu et al., 2011). When vapor moves from Sp-3 (3,900 m) to Sp-1 $(4,200 \mathrm{~m})$, as the altitude increases, precipitation first increases and then decreases. On the other hand, dust and ions carried by the atmosphere are also affected by elevation as they fall to the surface of the glacier as dry deposition. Numerous studies have shown that the higher the altitude, the lower the concentration of dust particles. For instance, the concentration of dust particles in snow pits in Rongbuk Glacier in the Everest Mountains $(6,000 \mathrm{~m})$ is significantly lower than that of eastern Tian Shan $(4,000 \mathrm{~m})$, while the concentration of dust particles on glaciers of Tian Shan is much lower than that of Tateyama Mountain $(2,100 \mathrm{~m})$ in central Japan (Osada et al., 2004; Wu and Yao, 2005; Dong et al., 2009).

In addition, at different depths in the snow pits, the concentrations of dust particles and ions also showed obvious variation. The influencing factors may include the water vapor source for the glacier area, sand and dust activity, and meltwater leaching of the snow layer (Wake et al., 1994). Taking Sp-3 as an example (Figure 3), the concentration of dust particles and ions increased significantly from depths of $40-60 \mathrm{~cm}$ in the snow pit where it peaked. There was also an upward trend from 80 to $100 \mathrm{~cm}$. Analysis suggests that this phenomenon must be closely related to the distribution of the dust layer in the snow pits. 

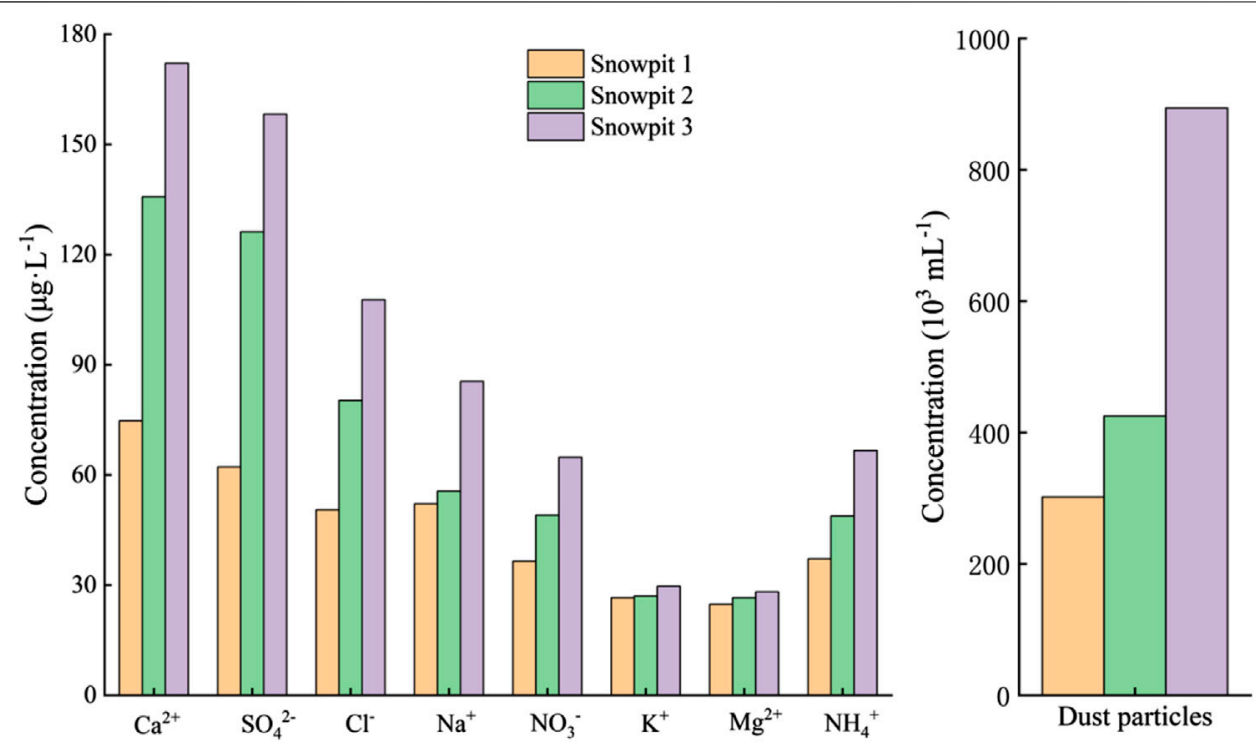

FIGURE 2 | Concentrations of ions and dust particles in snow pits at the study area.

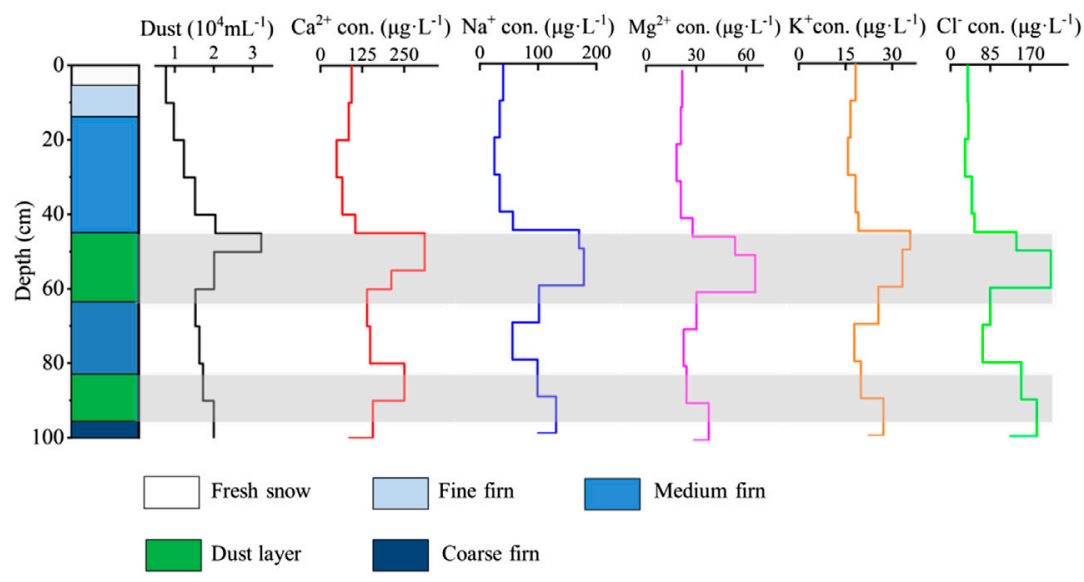

FIGURE 3 | Variations in dust and ions with depth in Snow pit 3.

During sampling in Sp-3, we found a thick fouling layer between 40 and $60 \mathrm{~cm}$. There was also a dust layer at the bottom of $\mathrm{Sp}-3$ that extended to the ice surface, which reflected the occurrence of atmospheric dust activity events. The annual period of sand and dust presence is from March to April each year in the Tian Shan Mountains, Xinjiang, with the frequency of sandstorms being highest in April (Li et al., 2014). Therefore, we suppose that the formation time of the dust layer at $80-100 \mathrm{~cm}$ depth in Sp-3 is likely to be the spring of 2017, while the 40 - to 60 -cm dust layer may well have formed in the spring of 2018. After the dust layer formed in spring 2017, the peak melting period occurred (July-August), and the concentrations of dust particles and ions in the snow layer were greatly depleted due to leaching. Because pit Sp-3 was excavated in early June 2018, the temperature had warmed, and the dust particles and ions in the upper layer $(40-60 \mathrm{~cm})$ were subject to some leaching, although the leaching effect was far less than that in the lower layer $(80-100 \mathrm{~cm})$. Although leaching of ions from the upper layer may also be a potential cause of the increased ion concentration in the lower layer, the contents of dust particles and ions in the upper layer $(40-60 \mathrm{~cm})$ were still higher than in the lower layer $(80-100 \mathrm{~cm})$. At the same time, we also analyzed the vertical gradient in dust particle concentration in pit Sp-3, which showed a trend of rising-falling-rising between 0 and $100 \mathrm{~cm}$. Therefore, the vertical gradient in dust particles needs to be described in two stages: 1) from 0 to $40 \mathrm{~cm}$, the concentration increased by $0.32 \mathrm{ml}^{-1} \times 10^{4} \mathrm{ml}^{-1}$ for every $10-\mathrm{cm}$ increase in depth, reaching a peak at $40-60 \mathrm{~cm}$. 2) From 60 to $80 \mathrm{~cm}$, the concentration increased by $0.15 \mathrm{ml}^{-1} \times 10^{4} \mathrm{ml}^{-1}$ for every $10 \mathrm{~cm}$, reaching a peak at $80-100 \mathrm{~cm}$. 

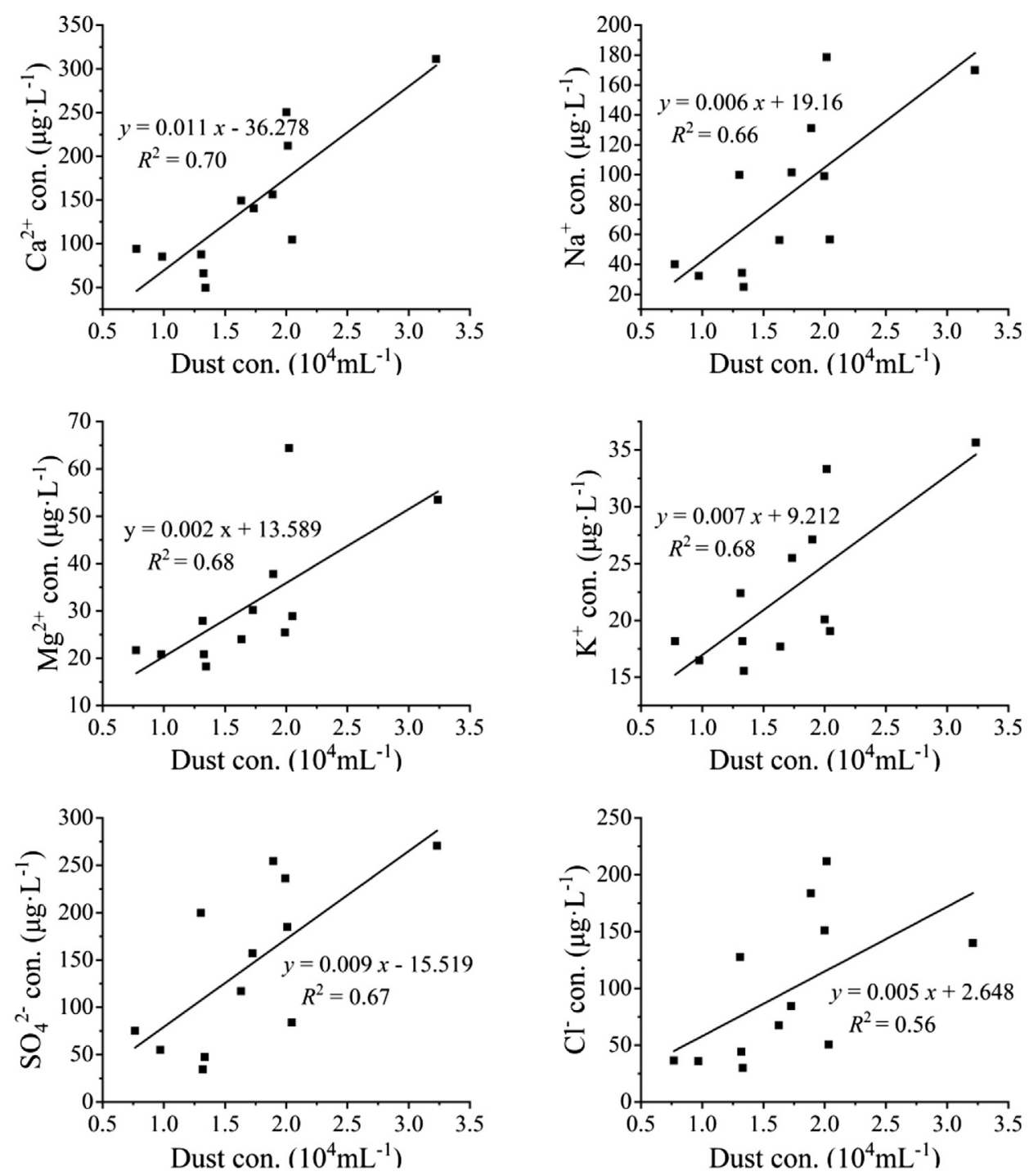

FIGURE 4 | Relationships between concentrations of dust and each of the major ions in snow, with linear models fitted.

In addition, we conducted a regression analysis on dust particle and major ion concentrations (Figure 4). Dust concentration was linearly related to the concentrations of $\mathrm{Ca}^{2+}, \mathrm{Na}^{+}, \mathrm{K}^{+}, \mathrm{Mg}^{2+}, \mathrm{SO}_{4}{ }^{2-}$, and $\mathrm{Cl}^{-}$ions, most strongly for $\mathrm{Ca}^{2+}\left(R^{2}=0.70\right)$. Previous research has found that the concentrations of $\mathrm{Ca}^{2+}, \mathrm{Mg}^{2+}$ and $\mathrm{SO}_{4}{ }^{2-}$ in snow pits in Urumqi Glacier No. 1 (Tian Shan Mountains) vary seasonally and in relation to dust activity ( $\mathrm{Li}$ et al., 2010). In this study, the concentrations of dust particles and major ions in pit $\mathrm{Sp}-3$ peaked in the dust layer, and the dust particle concentrations were highly correlated with those of $\mathrm{Ca}^{2+}, \mathrm{Mg}^{2+}$ and $\mathrm{SO}_{4}{ }^{2-}$ (Figure 4). It also can be seen that the $\mathrm{Na}^{+}$and dust particles varied in very similar ways in Sp-3. According to analyses of the environment surrounding the Tian Shan Mountains (Olivier, 2003; Wu and Yao, 2005; Zhang and Edwards, 2011), it was concluded that most $\mathrm{Na}^{+}$in the snow comes from a sand-dust source area of inland Central Asia that is rich in salt mines. In addition, $\mathrm{Ca}^{2+}$ is a tracer of mineral particles from the deserts and loess regions of the Asian continent and an indicator of dust from the Asian source region (Kazuo et al., 2004). In addition, the concentrations and sizes of particles are greater in the dust layer and lesser in the nondust layer. Meanwhile, the settling of particles in the dust layer brings many chemical components to the land surface and atmosphere, which makes the ionic concentration in the snow layer appear to be very high. The significant correlation between the high concentrations of dust particles and main ions. Therefore, seasonal variation in the regional atmospheric environment is the main reason why the concentrations of chemical ions and dust particles in snow at Glacier No. 6 vary with depth.

\section{Seasonal Variation of Dust Particles}

The study area is located in the center of the arid and semi-arid regions of northwest China and the source area for Central Asian 


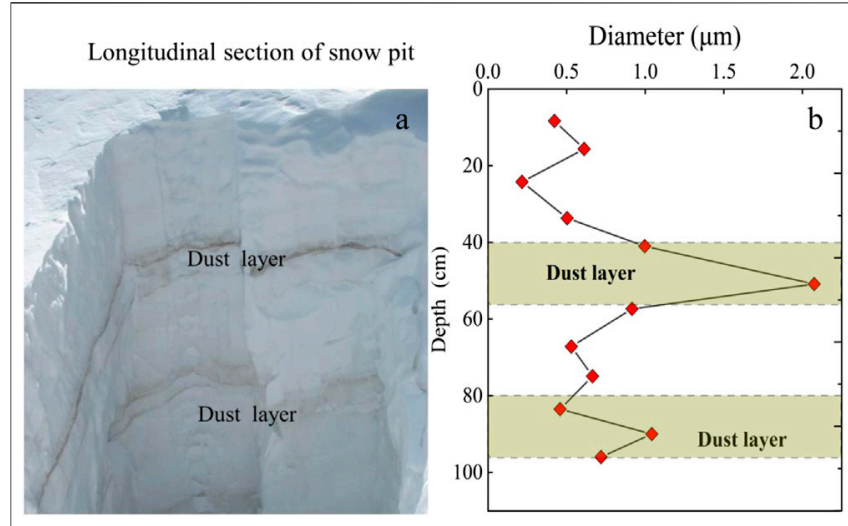

FIGURE 5 | Image of snow pit (A) and variation in dust diameter with depth (B).

dust activity. Sandstorm activity is an important feature of the atmospheric environment in this area. Due to the geographical location, the ions and dust particles in high-altitude snow and ice differ significantly between the springtime dust period and the non-dust period. The mean diameter of dust particles in the dust layer always reflects the dust mass concentration, because greater mean diameters are associated with more coarse particles and a greater dust mass concentration. Figure 5 shows the variation in dust diameter along the longitudinal section of the Sp-3. It can be seen that the dust diameter differs significantly with depth; that is, the mean diameter is high in the dust layer and low in the non-dust layer. This variation indicates that the Yushugou Glacier area is significantly affected by the dust activity of Central Asia.

Figure 6 shows that the mass-size distribution of dust particles in the snow can be approximated by a single model in the non-dust period and a multi-structure model in the dust period. The single distribution model reflects a single source, while the multi-structure distribution model indicates a complex source. Dust particle size distributions are not only related to the transporting winds but also the material sources. In snow samples collected in the non-dust period, dust particle sizes were concentrated in the range of $0.6-40.7 \mu \mathrm{m}$ (mean $=10.8 \mu \mathrm{m}$ ); when the size is $9.5 \mu \mathrm{m}$, the particle mass tends to be the greatest (Figure 6A). It is concluded that particles in snow samples from the non-dust period are fine particles transported by westerly winds with long-distance transport. Some studies have proven that in the process of atmospheric dust transport, longer distances result in better particle size separation, causing lower particle concentration and deposition flux in snow and ice (Zdanowicz et al., 1998). For example, it takes a long time for dust to travel from the source to the North Pole, which causes atmospheric aerosol particle concentrations to drop to fairly low levels (Wake et al., 1994; Wei et al., 2005). The multi-structure distribution model refers to the samples taken during the dust period (Snow samples collected from dust layers; Figure 6B, in which particle diameters range from 0.3 to $72.6 \mu \mathrm{m}$ ). When the diameter is 10 and $40 \mu \mathrm{m}$, the concentration of dust particles reaches a peak. The results show that particles from the dust period samples were mainly coarse mineral dust $(18.7-72.6 \mu \mathrm{m})$, which is mainly controlled by dust activity. The study area has high wind speeds during the dust period, which can bring a large number of dust particles. For example, the Taklimakan Desert and the Mongolian Desert near the Tian Shan Mountains provide material for the coarse particles found in snow and ice (Dong et al., 2009; Zhang and Edwards, 2011; Chen et al., 2015). In addition, there was a small amount of fine dust $(0.3-18.7 \mu \mathrm{m})$, which comes from long-distance dust that is present year-round and is mainly controlled by westerly winds. In general, the snow of Yushugou Glacier No. 6 is significantly affected by Central Asian dust activity, and the particle size distributions of insoluble particles differ significantly between the dust and non-dust periods.

\section{Source Analysis of Major lons in Snow Pits}

We used factor analysis to analyze the source of the major ions. The results show that the chemical composition of glacier No. 6 can be divided into three groups: group $1\left(\mathrm{Cl}^{-}, \mathrm{Na}^{+}\right.$, and $\left.\mathrm{K}^{+}\right)$, group $2\left(\mathrm{NH}_{4}{ }^{+}, \mathrm{NO}_{3}{ }^{-}\right.$, and $\left.\mathrm{SO}_{4}{ }^{2-}\right)$, and group $3\left(\mathrm{Ca}^{2+}, \mathrm{Mg}^{2+}\right.$, and dust; Table 2).
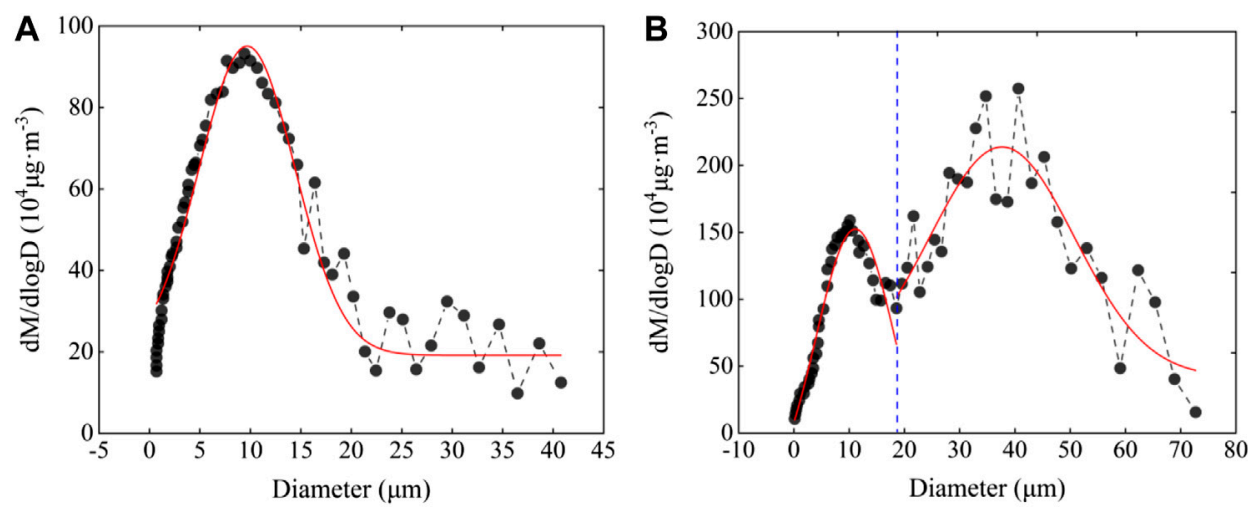

FIGURE 6 | Mass-size distributions of dust in snow at Yushugou Glacier No. 6 during the (A) non-dust and (B) dust periods. 
TABLE 2 | Factor loading matrix for ions in snow pits at Yushugou Glacier No. 6.

\begin{tabular}{lcccc}
\hline \multirow{2}{*}{ Element } & Communality & \multicolumn{3}{c}{ Factor loadings } \\
\cline { 3 - 5 } & & Factor $\mathbf{1}$ & Factor 2 & Factor 3 \\
\hline Dust & 0.922 & 0.376 & 0.345 & $\mathbf{0 . 8 5 7}$ \\
$\mathrm{Ca}^{2+}$ & 0.765 & $\mathbf{0 . 7 1 4}$ & 0.254 & $\mathbf{0 . 7 8 9}$ \\
$\mathrm{SO}_{4}{ }^{2-}$ & 0.783 & 0.357 & $\mathbf{0 . 7 3 6}$ & 0.237 \\
$\mathrm{Cl}^{-}$ & 0.841 & $\mathbf{0 . 7 8 4}$ & 0.432 & 0.313 \\
$\mathrm{Na}^{+}$ & 0.862 & $\mathbf{0 . 8 0 3}$ & 0.238 & 0.341 \\
$\mathrm{NO}_{3}{ }^{-}$ & 0.716 & -0.065 & $\mathbf{0 . 7 6 9}$ & 0.283 \\
$\mathrm{Mg}^{2+}$ & 0.842 & 0.364 & 0.031 & $\mathbf{0 . 8 3 6}$ \\
$\mathrm{K}^{+}$ & 0.733 & $\mathbf{0 . 7 4 5}$ & 0.139 & 0.368 \\
$\mathrm{NH}_{4}{ }^{+}$ & 0.751 & 0.522 & $\mathbf{0 . 6 2 4}$ & 0.031 \\
Fraction of variance (\%) & & 39.3 & 27.8 & 19.2 \\
Cumulative (\%) & \multicolumn{4}{c}{86.3} \\
\end{tabular}

Notes: principal component loadings $>0.6$ shown in bold.

TABLE 3 | Correlations between ion and dust concentrations in snow pits at Yushugou Glacier No. 6 (Person correlation coefficient).

\begin{tabular}{lcccccccc}
\hline & $\mathbf{C l}^{-}$ & $\mathbf{N O}_{3}{ }^{-}$ & $\mathbf{S O}_{4}{ }^{2-}$ & $\mathbf{N a}^{+}$ & $\mathbf{N H}_{4}{ }^{+}$ & $\mathbf{K}^{+}$ & $\mathbf{M g}^{2+}$ & $\mathbf{C a}^{2+}$ \\
\hline $\mathrm{NO}_{3}{ }^{-}$ & 0.75 & & & & & & & \\
$\mathrm{SO}_{4}{ }^{2-}$ & $0.78^{*+}$ & 0.9 & & & & & & \\
$\mathrm{Na}^{+}$ & 0.91 & $0.53^{*}$ & 0.62 & & & & & \\
$\mathrm{NH}_{4}{ }^{+}$ & 0.81 & 0.86 & 0.93 & 0.64 & & & & \\
$\mathrm{~K}^{+}$ & $0.71^{*}$ & 0.32 & $0.46^{*}$ & $0.75^{*}$ & 0.68 & & & \\
$\mathrm{Mg}^{2+}$ & $0.7^{+*}$ & 0.34 & $0.65^{*+}$ & $0.67^{*+}$ & $0.82^{+*}$ & $0.92^{*+}$ & & \\
$\mathrm{Ca}^{2+}$ & $0.55^{*}$ & $0.4^{*}$ & $0.82^{*+}$ & $0.49^{*}$ & $0.86^{*+}$ & $0.81^{*+}$ & $0.94^{*+}$ & \\
Dust & 0.78 & 0.47 & 0.76 & 0.58 & 0.55 & 0.71 & 0.77 & 0.93 \\
\hline${ }^{*} \mathrm{p}<0.05$. & & & & & & & \\
${ }^{* *} \mathrm{p}<0.01$. & & & & & & & \\
\end{tabular}

Factor 1 loadings are the highest in $\mathrm{Cl}^{-}, \mathrm{Na}^{+}$, and $\mathrm{K}^{+}$, which have good correlations with each other (Table 3). In the northwestern Tian Shan Mountains, there are large salt lakes (Alar Lake, Aibi Lake, Isek Lake, etc.) with high salt contents, and surrounding salt mineral resources are abundant. Under dry, high-temperature climatic conditions, salt lakes evaporate and salt particles rich in $\mathrm{Na}^{+}, \mathrm{Cl}^{-}$, and $\mathrm{K}^{+}$ are carried to glacier areas by westerly winds. There are conflicting opinions on the sources of $\mathrm{Na}^{+}$and $\mathrm{Cl}^{-}$in the typical glacier snow cover at the Tian Shan Mountains. One study suggests that the $\mathrm{Na}^{+}$and $\mathrm{Cl}^{-}$ions are mainly derived from terrestrial dust and evaporation of surrounding salt lakes (Olivier, 2003). Other studies have found that at least half of the $\mathrm{Na}^{+}$and $\mathrm{Cl}^{-}$originates from sea salt (Dong et al., 2011; Zhang and Edwards, 2011). In this study, the sea salt tracer method was used to calculate the marine sources of $\mathrm{Na}^{+}$and $\mathrm{Cl}^{-}$(41 and 34\%). It was concluded that the $\mathrm{Na}^{+}$and $\mathrm{Cl}^{-}$in the snow at Yushugou Glacier No. 6 have not only terrestrial sources (terrestrial dust and salt lake evaporation) but also some sea salt input.

Factor 2 loadings were highest for $\mathrm{NH}_{4}{ }^{+}, \mathrm{NO}_{3}{ }^{-}$, and $\mathrm{SO}_{4}{ }^{2-}$, which also had good correlations with each other (Table 3 ). This factor is explained as a component with anthropogenic sources, including burning of fossil fuels and biomass, emissions from livestock and poultry waste, and natural fertilizers. Mineral dust is usually the carrier of such pollutants (Bernabe et al., 2005). Although the area is relatively sparsely populated, glacier No. 6 is only $80 \mathrm{~km}$ from Hami Prefecture in the Xinjiang Uygur Autonomous Region, which has more than 600,000 residents. Air pollutants in Hami Prefecture may have been transported to the glacier through low-level regional atmospheric circulation. According to the sea salt calculation formula, non-marine sources accounted for 85 and $89 \%$ of the $\mathrm{NO}_{3}{ }^{-}$ and $\mathrm{NH}_{4}{ }^{+}$in the snow cover at No. 6 glacier, respectively. Combined with the coefficient of correlation between $\mathrm{NO}_{3}{ }^{-}$ and $\mathrm{NH}_{4}{ }^{+}(0.86)$, it can be inferred that the source of these ions is mainly terrestrial. It is generally believed that atmospheric $\mathrm{NO}_{3}{ }^{-}$and $\mathrm{NH}_{4}{ }^{+}$are generally caused by the combustion of biological and fossil fuels (secondary reactions of $\mathrm{NO}_{\mathrm{X}}$ ), chemical fertilizers, motor vehicle exhaust, industrial emissions, and other human activities (Van der A. et al., 2017). The study area is located in the eastern Tian Shan Mountains, which is a typical continental climate area. The westerly winds play a leading role in this area. The air mass passes through central Asia and Xinjiang from west to east, carrying $\mathrm{NO}_{3}{ }^{-}, \mathrm{NH}_{4}{ }^{+}$, and $\mathrm{SO}_{4}{ }^{2-}$ along the way, and eventually reaches the glacier area. In addition, natural pastures are widely distributed around the Tian Shan Mountains, which have a high livestock load, frequent agricultural and animal husbandry activities in summer and autumn, and high rates of biomass combustion (straw and firewood), decomposition of animal excreta and corpses, and fertilizer use, which all produce $\mathrm{NO}_{\mathrm{X}}$ and $\mathrm{NH}_{3}$. The ions $\mathrm{SO}_{4}{ }^{2-}, \mathrm{Ca}^{2+}$, and $\mathrm{NO}_{3}{ }^{-}$were also significantly correlated. Moreover, the non-marine source accounted for $96 \%$ of the $\mathrm{SO}_{4}{ }^{2-}$, indicating that $\mathrm{SO}_{4}{ }^{2-}$ in glacial snow is not only derived from input of sand and minerals (such as central Asian dust containing large amounts of $\mathrm{CaSO}_{4}$ and other sulfates) but also from anthropogenic emissions of sulfur pollutants (such as from coal and oil combustion).

Factor 3 loadings were highest in $\mathrm{Ca}^{2+}$ and $\mathrm{Mg}^{2+}$, which were also significantly correlated. Many studies have shown that the main chemical components in Asian dust are $\mathrm{Ca}^{2+}$ and $\mathrm{Mg}^{2+}$, and their concentrations are closely related to the dust concentration. The analysis shows that $\mathrm{Ca}^{2+}, \mathrm{Mg}^{2+}, \mathrm{K}^{+}$, and particles are transported by atmospheric circulation and, after reaching the glacier area, become attached to the snow layer by dry and wet sedimentation, finally forming a dust layer with obvious seasonal characteristics. This phenomenon is similar to the sandstorm weather process occurring in winter and spring, at which time the major chemical ions were observed to peak in the snow pits at glaciers No. 72 and No. 1 in the Tian Shan Mountains. The study area is mainly influenced by westerly winds and is surrounded by large deserts. As the westerly winds pass through the deserts and Gobi, sand, gravel, and dust particles are transported to the surfaces of glaciers by the airflow. Therefore, the $\mathrm{Ca}^{2+}, \mathrm{Mg}^{2+}$, and $\mathrm{K}^{+}$ions in the snow, which are attached to the dust layer, can be classified as having relatively remote sand and dust sources. 
TABLE 4 | Concentrations of major ions $\left(\mu \mathrm{eq} \mathrm{L}^{-1}\right)$ in snow at various glaciers in China.

\begin{tabular}{|c|c|c|c|c|c|}
\hline Site & $\begin{array}{c}\text { Yushugou Glacier } \\
\text { No. } 6 \\
\text { (this study) }\end{array}$ & $\begin{array}{c}\text { Altai, Belukha } \\
\text { Glacier (Olivier, } \\
\text { 2003) }\end{array}$ & $\begin{array}{c}\text { Tian Shan, } \\
\text { Urumqi Glacier } \\
\text { No. } 1 \\
\text { (Li et al., } \\
\text { 2010) }\end{array}$ & $\begin{array}{l}\text { Himalayas, East } \\
\text { Rongbuk Glacier } \\
\text { (Gen et al., } \\
\text { 2007) }\end{array}$ & $\begin{array}{c}\text { Yu Long, } \\
\text { Baishui Glacier } \\
\text { No. } 1 \\
\text { (Li et al., } \\
\text { 2007) }\end{array}$ \\
\hline Elevation (m a.m.l.) & 4,177 & 3,800 & 4,130 & 6,450 & 4,600 \\
\hline $\mathrm{Ca}^{2+}$ & 13.6 & 3.9 & 33.9 & 5.3 & 1.8 \\
\hline $\mathrm{Na}^{+}$ & 3 & 1.6 & 4.2 & 0.5 & 0.02 \\
\hline $\mathrm{Mg}^{2+}$ & 2.3 & 0.7 & 7.8 & 0.4 & 0.04 \\
\hline $\mathrm{K}^{+}$ & 0.7 & 0.9 & 0.8 & 0.2 & 0.02 \\
\hline $\mathrm{NH}_{4}^{+}$ & 2.6 & 4.7 & 8.1 & 3.0 & \\
\hline $\mathrm{SO}_{4}^{2-}$ & 2.9 & 4.0 & 8.6 & 1.9 & 0.4 \\
\hline $\mathrm{Cl}^{-}$ & 2.4 & 1.4 & 4.5 & 0.5 & 0.1 \\
\hline $\mathrm{NO}_{3}^{-}$ & 0.91 & 3.5 & 4.0 & 0.7 & 0.3 \\
\hline Total & 28.41 & 20.7 & 71.9 & 12.5 & 2.68 \\
\hline
\end{tabular}
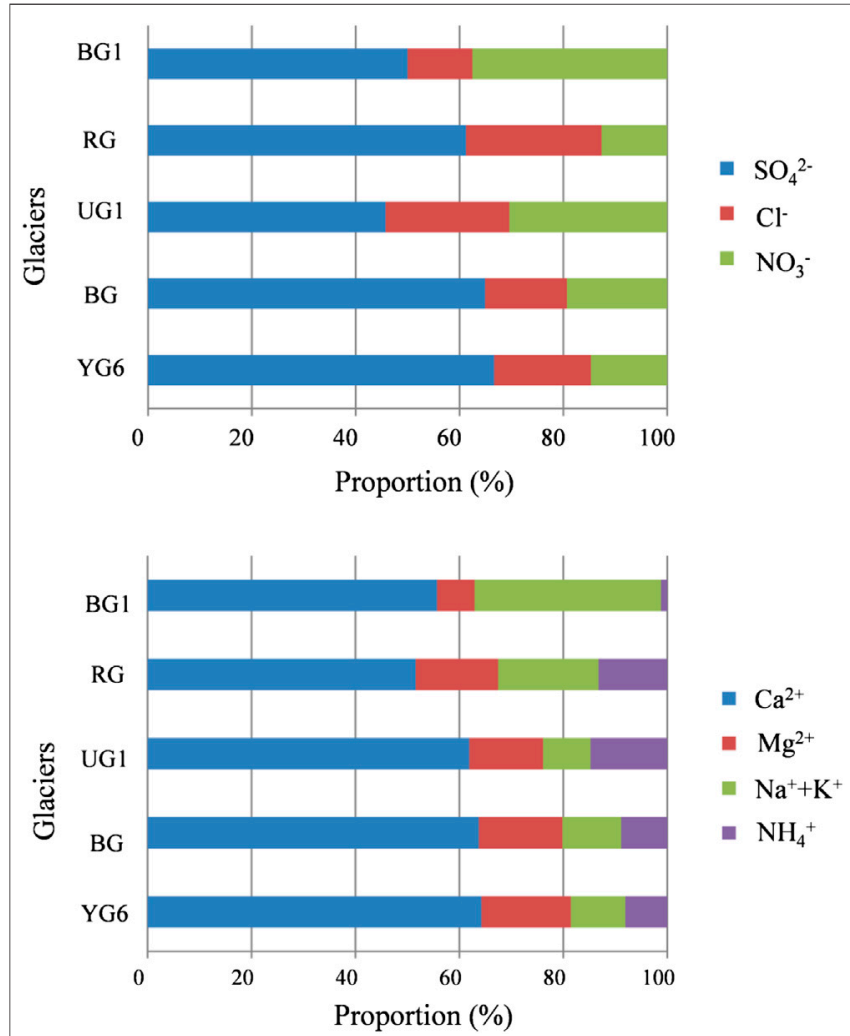

FIGURE 7 | Proportions of major ions in snow pits at various glaciers. YG6, Yushugou Glacier No. 6; BG, Belukha Glacier; UG1, Urumqi Glacier No. 1; RG, Rongbuk Glacier; BG1, Baishui Glacier No. 1.

\section{DISCUSSION}

\section{Comparison of the Chemical Characteristics of Snow in Different Glacier Regions}

To explain the regional characteristics of chemical ion deposition in the snow pits, this study compared and analyzed the ion contents and compositions of glaciers in other regions. Table 4 shows that the concentrations of chemical ions in the snow cover of glaciers in the Tian Shan Mountains and Altai Mountains are generally higher, while those at the East Rongbuk Glacier $(6,450 \mathrm{~m})$ and Marine Baishui Glacier No. 1 are lower. This reflects spatial differences in chemical ion deposition in snow. In particular, the concentrations of ions in glacial snow cover within the Asian dust source area are generally higher, while those in the Marine Glaciers are lower. This indicates that land-sourced minerals may have a significant influence on the chemical characteristics of the snow cover. Figure 7 shows the percentages of chemical ions in different glacier regions. The cationic percentage characteristics of Yushugou Glacier No. 6 are extremely similar to those of Urumqi Glacier No. 1 and Belukha Glacier. The percentages of $\mathrm{Ca}^{2+}, \mathrm{Mg}^{2+}$, and $\mathrm{Na}^{+}+\mathrm{K}^{+}$in the snow pits of Yushugou Glacier No. 6 are higher than those of East Rongbuk Glacier and Baishui Glacier No. 1, indicating that land minerals have a great influence on the chemical characteristics of glacier snow. In the anion composition diagram, the percentages of anions in the snow of different glaciers are significantly different. The percentages of $\mathrm{SO}_{4}{ }^{2-}$ and $\mathrm{Cl}^{-}$in the snow of Yushugou Glacier No. 6 are higher than those of other glaciers, while the percentage of $\mathrm{NO}_{3}{ }^{-}$in Yushugou Glacier No. 6 is lower and close to that of Rongbuk Glacier. This reflects the regional differences in the chemical compositions of snow in different glaciers. Overall, the proportions of $\mathrm{NH}_{4}^{+}$and $\mathrm{NO}_{3}^{-}$in the snow of Yushugou Glacier No. 6 are very low, which indicates that the glacier area is relatively unaffected by regional anthropogenic pollution (such as biomass combustion and fertilization).

Air Mass Transport Path During Dust Events Figure 8 shows the results of the backward trajectory analysis of air mass transport to the sampling sites at Yushugou Glacier No. 6 during the dust period. According to the observational data of many meteorological stations (Hami Station, Alashan Station, Urumqi Station, etc.), we counted several large-scale sandstorm events from 2017 to 2018 and simulated their air mass transport paths to Yushugou Glacier No. 6. Figure 8A shows the track of the sandstorm air masses on August 30, 2017, in which the upper air mass from the southwest originated in Afghanistan, while the 


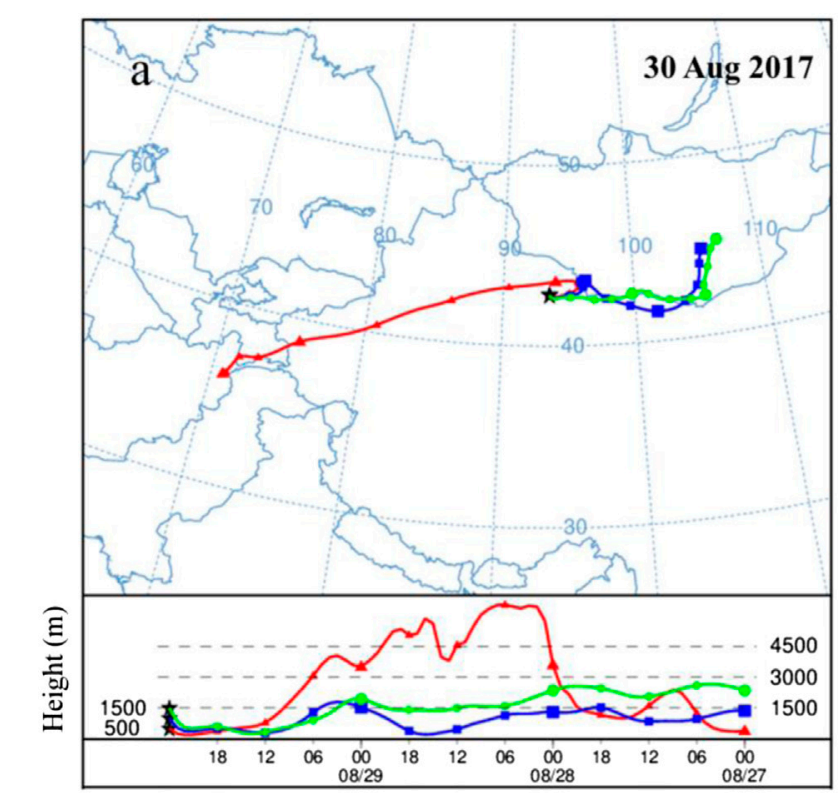

Date

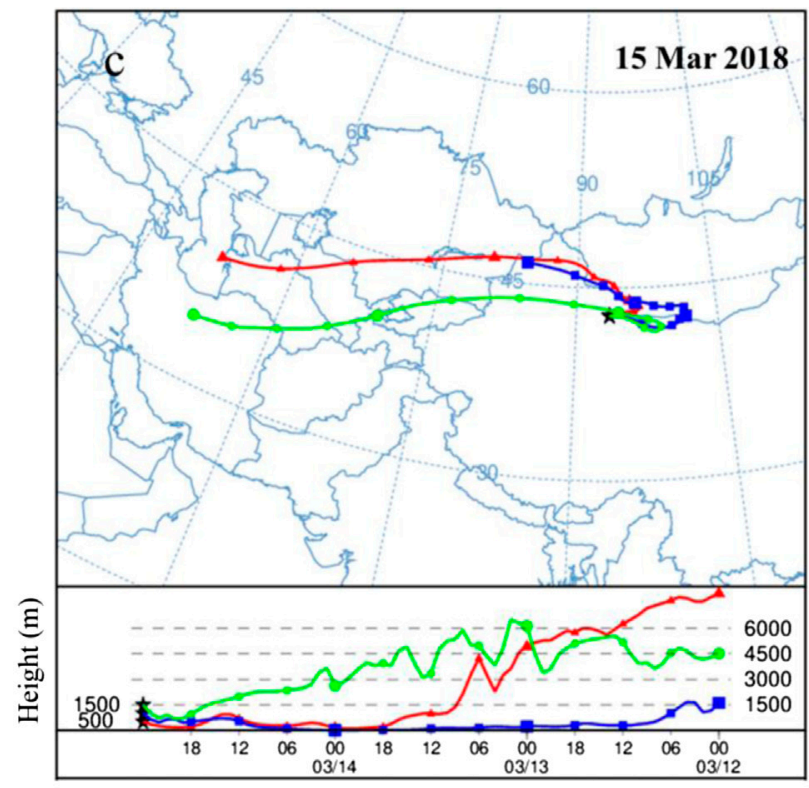

Date

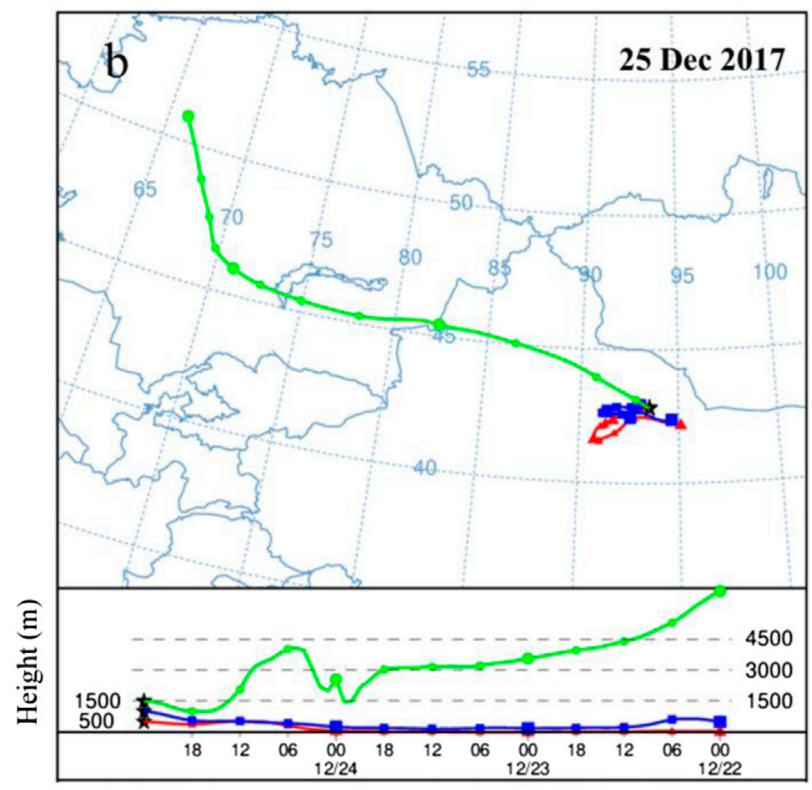

Date

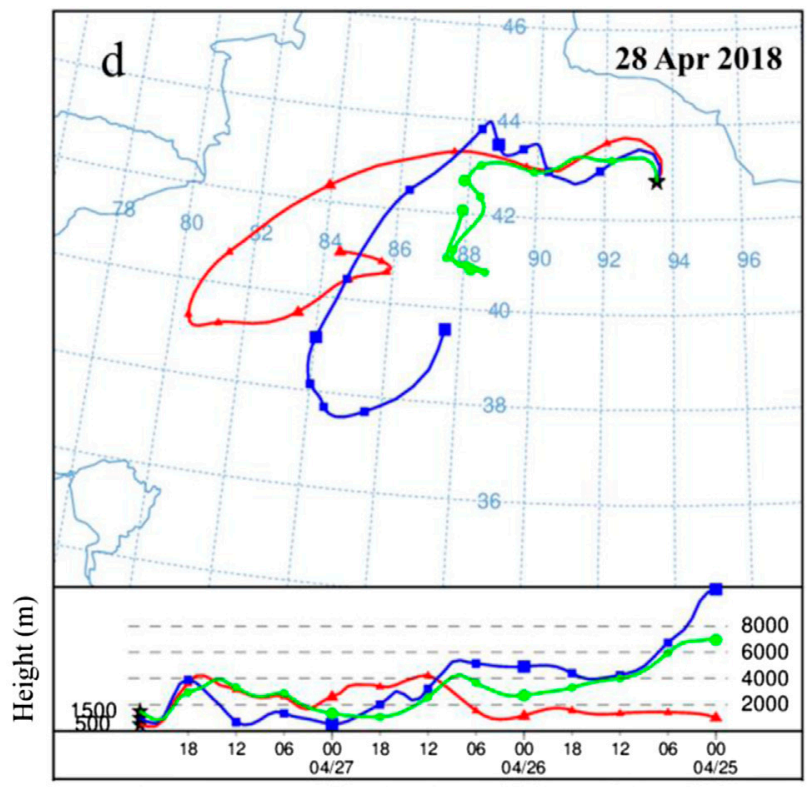

Date

FIGURE 8 | Backward trajectory analysis of several large-scale sandstorm air masses that reached Yushugou Glacier No. 6 during the study period (2017 and 2018).

lower air mass from the east originated in Mongolia. In the sandstorm event on December 25, 2017, the long-path air mass originated in Kazakhstan, while the short-path air mass came from the local deserts and Gobi (Figure 8B). Figure $\mathbf{8 C}$ shows the dust storm air masses on March 15, 2018. These air masses originated from the Caspian Sea coast and crossed Central Asia from west to east until they reached glacier No. 6. The sandstorm air mass on December 25, 2017, originated from the Taklimakan Desert (Figure 8D). In conclusion, when sandstorms occurred at Yushugou Glacier No. 6, the air masses mainly came from
Mongolia, the Tarim Basin, and Central Asia. It is surrounded by the Taklimakan Desert, Gulbantonggu Desert, and Kumtag Desert (Chen et al., 2015), which are important sources of the dust particles, $\mathrm{Ca}^{2+}$ and $\mathrm{Mg}^{2+}$, found in the snow at Yushugou Glacier No. 6 .

\section{CONCLUSIONS}

This study analyzed the chemical ion characteristics and environmental significance of snow samples from pits and the 
surface of Yushugou Glacier No. 6, Tian Shan, based on field sampling, experimental detection, and data processing. We draw the following conclusions.

The ionic concentrations in snow at Yushugou Glacier No. 6 were ranked in order of highest to lowest as $\mathrm{Ca}^{2+}>\mathrm{SO}_{4}{ }^{2-}>\mathrm{Cl}^{-}>$ $\mathrm{Na}^{+}>\mathrm{NO}_{3}{ }^{-}>\mathrm{NH}_{4}{ }^{+}>\mathrm{Mg}^{2+}>\mathrm{K}^{+}$. Hence, $\mathrm{SO}_{4}{ }^{2-}$ was the dominate anion and $\mathrm{Ca}^{2+}$ was the dominant cation. The major ionic average concentrations, $\mathrm{pHs}$, and electrical conductivities in snow pits were higher than those in surface snow. This is because surface snow is formed from recent snowfall in the glacier area, while the snow in snow pits represents the accumulation of snowfall and atmospheric chemical deposition over a long period.

The concentrations of particles and ions in the snow had obvious seasonal variations, with high concentrations in spring (dust period) and low concentrations in summer (non-dust period). There was a significant difference in the mass-size distribution of particles in snow between the dust and nondust periods, which indicates that sandstorm activity in Central Asia has a significant influence on the concentrations of chemical ions and dust particles in the snow at Yushugou Glacier No. 6.

The sources of the ions in the snow at Yushugou Glacier No. 6 were mainly land mineral dust and human activities, with a small influence of marine sources. The $\mathrm{Ca}^{2+}, \mathrm{Mg}^{2+}$, and $\mathrm{K}^{+}$ions in snow pits were generally classified as long-distance land-sourced mineral dust. The $\mathrm{Na}^{+}$and $\mathrm{Cl}^{-}$ions had a terrestrial source with partial sea salt input. The $\mathrm{NO}_{3}{ }^{-}, \mathrm{NH}_{4}{ }^{+}$, and $\mathrm{SO}_{4}{ }^{2-}$ ions were mainly sourced from human industrial and agricultural activities

\section{REFERENCES}

Bernabé, J. M., Carretero, M. I., and Galán, E. (2005). Mineralogy and origin of atmospheric particles in the industrial area of Huelva (SW Spain). Atmos. Environ. 39 (36), 6777-6789. doi:10.1016/j.atmosenv. 2005.07.073

Blifford, I. H., and Meeker, G. O. (1967). A factor analysis model of large scale pollution. Atmos. Environ. 1 (2), 147-157. doi:10.1016/0004-6981(67)90042-x

Chen, W., Li, Z., and Hu, B. (2015). The ionic concentration characteristics in snow pits of Miaoergou Glacier, Tian Shan, Hami Prefecture. J. Environ. Chem. 34 (12), 2307-2309 [in Chinese, with English summary].

Church, T. M., Galloway, J. N., Jickells, T. D., and Knap, A. H. (1982). The chemistry of western Atlantic precipitation at the mid-Atlantic coast and on Bermuda. J. Geophys. Res. 87 (C13), 11013-11018. doi:10.1029/ jc087ic13p11013

Dahe, Q., Shiyin, L., and Peiji, L. (2006). Snow cover distribution, variability, and response to climate change in western China. J. Clim. 19 (9), 1820-1833. doi:10. 1175/jcli3694.1

Dibb, J., Whitlow, S., and Arsenault, M. (2007). Seasonal variations in the soluble ion content of snow at Summit. Greenland: Constraints from three years of daily surface snow samples. Atmos. Environ. 41 (24), 5007-5019. doi:10.1016/j. atmosenv.2006.12.010

Dong, Z., Li, Z., Wang, F., and Zhang, M. (2009). Characteristics of atmospheric dust deposition in snow on the glaciers of the eastern Tien Shan, China. J. Glaciol. 55 (193), 797-804. doi:10.3189/002214309790152393

Dong, Z., Li, Z., Zhang, M., Wang, F., and Wu, L. (2011). Physico-chemical characteristics and environmental significance of snow deposition on Haxilegen glacier No. 51 in Tian Shan, China. J. Mt. Sci. 8 (3), 484-494. doi:10.1007/ s11629-011-1012-3

Dong, Z., Qin, D., Chen, J., Qin, X., Ren, J., Cui, X., et al. (2014). Physicochemical impacts of dust particles on alpine glacier meltwater at the Laohugou Glacier (combustion of biological and fossil fuels, industrial emissions). In addition, a small amount of $\mathrm{SO}_{4}{ }^{2-}$ was sourced from sand and dust minerals.

\section{DATA AVAILABILITY STATEMENT}

All datasets generated for this study are included in the article/supplementary files.

\section{AUTHOR CONTRIBUTIONS}

All authors contributed to the development of the research question and general conceptual approach. PW, XZ, XZ, and MS developed and applied the statistical analysis and led the writing and production of the manuscript. FW and $\mathrm{HZ}$ assisted with access to collect data and precipitation sample.

\section{FUNDING}

This work was supported by The Second Tibetan Plateau Scientific Expedition and Research (2019QZKK0201), the Strategic Priority Research Program of Chinese Academy of Sciences (Class A) (XDA20060201; XDA20020102), the National Natural Science Foundation of China (41761134093; 41471058), and The SKLCS founding (SKLCS-ZZ-2020).

basin in western Qilian mountains, China. Sci. Total Environ. 493, 930-942. doi:10.1016/j.scitotenv.2014.06.025

Dong, Z., Qin, D., and Ren, J. (2013). Characteristics of atmospheric dust deposition in snow on the glaciers of western Qilian Mountains. Acta Geogr. Sin. 68 (1), 25-35. doi:10.11821/xb201301005

Du, Y., Sun, X., and Adiguzel, O. (2016). Estimation of NOx emission from fossil fuel consumption in China for the period 1980-2012. MATEC Web of Conferences. 64, 601-609. doi:10.1051/matecconf/20166406001

Eichler, A., Schwikowski, M., and Gäggeler, H. W. (2001). Meltwater-induced relocation of chemical species in Alpine firn. Tellus B 53 (2), 192-203. doi:10. 3402/tellusb.v53i2.16575

Fitzgerald, W. F., Engstrom, D. R., Mason, R. P., and Nater, E. A. (1998). The case for atmospheric mercury contamination in remote areas. Environ. Sci. Technol. 32 (1), 1-7. doi:10.1021/es970284w

Fuhrer, K., Neftel, A., Anklin, M., Staffelbach, T., and Legrand, M. (1996). Highresolution ammonium ice core record covering a complete glacial-interglacial cycle. J. Geophys. Res. 101 (D2), 4147-4164. doi:10.1029/95jd02903

Gen, Z., Hou, S., and Dong, Z. (2007). Major ions in ice cores and snow pits from the Himalayas: temporal and spatial variations and their sources. J. Glaciol. Geocryol. 29 (2), 191-200 [in Chinese, with English summary].

Jackson, T. A. (1997). Long-range atmospheric transport of mercury to ecosystems, and the importance of anthropogenic emissions-a critical review and evaluation of the published evidence. Environ. Rev. 5 (2), 99-120. doi:10.1139/a97-005

Kazuo, O., Hajime, I., and Mizuka, K. (2004). Mineral dust layers in snow at Mount Tateyama, Central Japan: formation processes and characteristics. Tellus B 56 (4), 382-392. doi:10.1111/j.1600-0889.2004.00108.x

Keene, W. C., Pszenny, A. A. P., Galloway, J. N., and Hawley, M. E. (1986). Sea-salt corrections and interpretation of constituent ratios in marine precipitation. J. Geophys. Res. 91 (D6), 6647. doi:10.1029/jd091id06p06647

Koven, C. D., Riley, W. J., and Stern, A. (2013). Analysis of permafrost thermal dynamics and response to climate change in the CMIP5 earth system models. J. Clim. 26 (6), 1877-1900. doi:10.1175/jcli-d-12-00228.1 
Kraaijenbrink, P. D. A., Bierkens, M. F. P., Lutz, A. F., and Immerzeel, W. W. (2017). Impact of a global temperature rise of 1.5 degrees Celsius on Asia's glaciers. Nature 549 (7671), 257-260. doi:10.1038/nature23878

Lammel, G., Brüggemann, E., Gnauk, T., Müller, K., Neusüss, C., and Röhrl, A. (2003). A new method to study aerosol source contributions along the tracks of air parcels and its application to the near-ground level aerosol chemical composition in central Europe. J. Aerosol Sci. 34 (1), 1-25. doi:10.1016/ s0021-8502(02)00134-9

Li, Z., He, Y., and Pang, H. (2007). Source of major anions and cations of snowpacks in the typical monsoonal temper ate glacial region of China. Acta Geogr. Sin. 62 (9), 992-1001.

Li, Z., Li, H., Dong, Z., and Zhang, M. (2010). Chemical characteristics and environmental significance of fresh snow deposition on Urumqi Glacier No. 1 of Tianshan Mountains, China. Chin. Geogr. Sci. 20 (5), 389-397. doi:10.1007/ s11769-010-0412-6

Li, W., Chen, L., and He, Q. (2014). Analysis of sandstorm frequency variation tendency of Xinjiang in recent 50 years. Environ. Protection of Xinjiang, 36 (3), 20-24 [in Chinese, with English summary]. doi:10.3969/j.issn.1008-2301.2014. 03.005

Liu, J., Chen, S., and Qin, W. (2011). Study on the vertical distribution of precipitation in mountainous regions using TRMM data. Shuikexue Jinzhan/ Adv. Water Sci. 22 (4), 447-454 [in Chinese, with English summary]. doi:10. 1007/s11589-011-0776-4

Liu, Y.-p., Geng, Z.-x., and Hou, S.-g. (2010). Spatial and seasonal variation of major ions in Himalayan snow and ice: a source consideration. J. Asian Earth Sci. 37 (2), 195-205. doi:10.1016/j.jseaes.2009.08.006

Luo, G., Liu, L., and Wu, L. (1999). Analysis of hydrological characteristics in the yiwu river basin. Arid. Land Geogr. 22 (1), 47-52 [in Chinese, with English summary]. doi:10.13826/j.cnki.cn65-1103/x.1999.01.007

Ma, X., and Luo, X. (2009). Analysis of the impact of climate change on runoff in the Yushugou basin. China Water Transport. 9 (10), 190-193 [in Chinese, with English summary]. doi:CNKI:SUN:ZSUX.0.2009-10-090

Massling, A., Nielsen, I., and Kristensen, D. (2015). Atmospheric black carbon and sulfate concentrations in northeast Greenland. Atmos. Chem. Phys. 15 (16), 11465-11493. doi:10.5194/acpd-15-11465-2015

Ming, J., Xiao, C., Cachier, H., Qin, D., Qin, X., Li, Z., et al. (2009). Black Carbon (BC) in the snow of glaciers in west China and its potential effects on albedos. Atmos. Res. 92, 114-123. doi:10.1016/j.atmosres.2008.09.007

Mukai, H., and Suzuki, M. (1996). Using air trajectories to analyze the seasonal variation of aerosols transported to the Oki Islands. Atmos. Environ. 30 (23), 3917-3934. doi:10.1016/1352-2310(96)00142-2

Niu, H., He, Y., Zhu, G., Xin, H., Du, J., Pu, T., et al. (2013). Environmental implications of the snow chemistry from Mt. Yulong, southeastern Tibetan Plateau. Quat. Int. 313-314, 168-178. doi:10.1016/j.quaint.2012.11.019

Niu, H., Kang, S., Zhang, Y., Shi, X., Shi, X., Wang, S., et al. (2017). Distribution of light-absorbing impurities in snow of glacier on Mt. Yulong, Southeastern Tibetan Plateau. Atmos. Res. 197, 474-484. doi:10.1016/j.atmosres.2017.07. 004

Olivier, S. (2003). Glaciochemical investigation of an ice core from Belukha glacier, Siberian Altai. Geophys. Res. Lett. 30 (19), 21-24. doi:10.1029/ 2003gl018290

Olivier, S., Blaser, C., Brütsch, S., Frolova, N., Gäggeler, H. W., Henderson, K. A., et al. (2006). Temporal variations of mineral dust, biogenic tracers, and anthropogenic species during the past two centuries from Belukha ice core, Siberian Altai. J. Geophys. Res. 111 (D5). doi:10.1029/ 2005jd005830

Osada, K., Iida, H., Kido, M., Matsunaga, K., and Iwasaka, Y. (2004). Mineral dust layers in snow at Mount Tateyama, Central Japan: formation processes and characteristics. Tellus B 56 (4), 382-392. doi:10.3402/tellusb.v56i4.16436

Prospero, J. M., Ginoux, P., Torres, O., Nicholson, S. E., and Gill, T. E. (2002). Environmental characterization of global sources of atmospheric soli dust identified with the nimbus 7 total ozone mapping spectrometer (TOMS) absorbing aerosol product. Rev. Geophys. 40 (1), 4-30. doi:10.1029/ 2000rg000095

Qin, D., Ding, Y., Xiao, C., Kang, S., Ren, J., Yang, J., et al. (2017). Cryospheric Science: research framework and disciplinary system. Natl. Sci. Rev. 5 (2), 255-268. doi:10.1093/nsr/nwx108
Qin, D., Liu, S., and Li, P. (2006). Snow cover distribution, variability, and response to climate change in western China. J. Clim. 19 (9), 1820-1833. doi:10.1175/ jcli3694.1

Qin, X., Qin, D., Huang, C., et al. (1999). Chemical characteristics of waters in rongbu glacier on mount everest. Environ. Sci. 20 (1), 1-6 [in Chinese, with English summary].

Ruth, U., Wagenbach, D., Steffensen, J. P., and Bigler, M. (2003). Continuous record of microparticle concentration and size distribution in the central Greenland NGRIP ice core during the last glacial period. J. Geophys. Res. 108 (D3), 4098. doi:10.1029/2002jd002376

Steffensen, J. P. (1997). The size distribution of microparticles from selected segments of the Greenland Ice Core Project ice core representing different climatic periods. J. Geophys. Res. 102 (C12), 26755-26763. doi:10.1029/ 97jc01490

Sugimoto, N., Nishizawa, T., Shimizu, A., Matsui, I., and Kobayashi, H. (2015). Detection of internally mixed Asian dust with air pollution aerosols using a polarization optical particle counter and a polarization-sensitive twowavelength lidar. J. Quant. Spectrosc. Radiat. Transf. 150, 107-113. doi:10. 1016/j.jpsrt.2014.08.003

Van der A, R. J., Mijling, B., Ding, J., Koukouli, M. E., Liu, F., and Li, Q. (2017). Cleaning up the air: effectiveness of air quality policy for $\mathrm{SO}_{2}$ and $\mathrm{NO}_{\mathrm{x}}$ emissions in China. Atmos. Chem. Phys. 17 (3), 1775-1789. doi:10.5194/acp17-1775-2017

Wake, C. P., Mayewski, P. A., Li, Z., Han, J., and Qin, D. (1994). Modern eolian dust deposition in central Asia. Tellus B 46 (3), 220-233. doi:10.1034/j.1600-0889. 1994.t01-2-00005.x

Wang, P., Yao, T., Tian, L., Wu, G., Li, Z., and Yang, W. (2008). Recent highresolution glaciochemical record from a Dasuopu firn core of middle Himalayas. Chin. Sci. Bull. 53 (3), 418-425 [in Chinese, with English summary]. doi:10.1007/s11434-008-0098-7

Wang, S., Zhang, M.-J., Li, Z.-Q., Wang, F.-T., and Zhang, X.-Y. (2013). Distribution and its environmental significance of nitrate and ammonium in snowpack of glaciers in Chinese Tianshan Mountains. Earth Sci. 38 (1), 201-210. 10.3799/dqkx.2013.021

Wang, S., Zhang, M., Pepin, N. C., Li, Z., Sun, M., Huang, X., et al. (2014). Recent changes in freezing level heights in High Asia and their impact on glacier changes. J. Geophys. Res. Atmos. 119 (4), 1753-1765. doi:10.1002/2013jd020490

Wang, X., Xiao, C., and Gao, X. (2017). Matters needing attention in collection and pretreatment of snow and ice samples in chemical analysis. J. Glaciol. Geocryol. 39 (5), 1075-1083 [in Chinese, with English summary]. doi:10.7522/j.issn.10000240.2017 .0119

Wang, X., Li, Z., and Jiang, C. (2017). Run-off analyses using isotopes and hydrochemistry in Yushugou River basin, eastern Tianshan Mountains. J. Earth Syst. Sci. 126 (6), 86. doi:10.1007/s12040-017-0858-3

Wei, J., Li, Y., and Tan, D. (2005). Review of research on insoluble micro-particles in the polar cores. Adv. Earth Sci. 20 (2), 216-222 [in Chinese, with English summary]. doi:10.3321/j.issn:1001-8166.2005.02.012

Wu, G., and Yao, T. (2005). Progress in studies on insoluble microparticle in ice cores. J. Glaciol. Geocryol. 27 (4), 528-538 [in Chinese, with English summary]. doi:CNKI:SUN:BCDT.0.2005-04-009

Wu, X., Li, Q., Wang, N., Pu, J. C., He, J. Q., and Zhang, C. W. (2011). Regional characteristics of ion concentration in glacial snow pits over the Tibetan Plateau and source analysis. Environ. Sci. 32 (4), 971-975. doi:10.1016/S1671-2927(11) 60313-1

You, X., Li, Z., and Wang, L. (2019). The relationship between meteorological elements and ice core record forming process and its resolution on Glacier No. 1 in headwater of Urumqi River, eastern Tianshan Mountains. J. Glaciol. Geocryol. 41 (2), 259-267. doi:10.7522/j.issn.1000-0240.2019.0065

Zdanowicz, C. M., Zielinski, G. A., and Wake, C. P. (1998). Characteristics of modern atmospheric dust deposition in snow on the penny ice cap, baffin island, arctic Canada. Tellus B 50(5), 506-520. doi:10.3402/tellusb.v50i5.16234

Zhang, X., and Edwards, R. (2011). Anthropogenic sulfate and nitrate signals in snow from Bogda Glacier, eastern Tianshan. J. Earth Sci. 22 (4), 490-502. doi:10.1007/s12583-011-0196-3

Zhang, Y., Kang, S., and Zhang, Q. (2007). Snow ice records on Mt. Geladandong in the central Tibetan Plateau. J. Glaciol. Geocryol. 29 (5), 686-693 [in Chinese, with English summary]. 
Zhu, Y., Li, Z., and You, X. (2006). Application and technique in glacier by Accusizer 780A optical particle size. Modern Sci. Apparatus. 3, 81-84 [in Chinese, with English summary].

Conflict of Interest: The authors declare that the research was conducted in the absence of any commercial or financial relationships that could be construed as a potential conflict of interest.
Copyright (c) $2020 \mathrm{Liu}, \mathrm{Li}$, Zhou, Wang, Zhang, Wang, Zhang and Song. This is an open-access article distributed under the terms of the Creative Commons Attribution License (CC BY). The use, distribution or reproduction in other forums is permitted provided the original author(s) and the copyright owner(s) are credited and that the original publication in this journal is cited, in accordance with accepted academic practice. No use, distribution or reproduction is permitted which does not comply with these terms. 